\title{
Major role of marine vegetation on the oceanic carbon cycle
}

\author{
C. M. Duarte ${ }^{1}$, J. J. Middelburg ${ }^{2}$, and N. Caraco $^{3}$ \\ ${ }^{1}$ IMEDEA (CSIC-UIB), Grupo de Oceanografía Interdisciplinar, C/Miquel Marqués 21, 07190 Esporles (Islas Baleares), \\ Spain \\ ${ }^{2}$ Netherlands Institute of Ecology (NIOO-KNAW), P.O. Box 140, 4400 AC Yerseke, The Netherlands \\ ${ }^{3}$ Institute of Ecosystem Studies, Box AB, Millbrook, NY12545, USA
}

Received: 10 September 2004 - Published in Biogeosciences Discussions: 7 October 2004

Revised: 14 January 2005 - Accepted: 27 January 2005 - Published: 1 February 2005

\begin{abstract}
The carbon burial in vegetated sediments, ignored in past assessments of carbon burial in the ocean, was evaluated using a bottom-up approach derived from upscaling a compilation of published individual estimates of carbon burial in vegetated habitats (seagrass meadows, salt marshes and mangrove forests) to the global level and a top-down approach derived from considerations of global sediment balance and a compilation of the organic carbon content of vegeatated sediments. Up-scaling of individual burial estimates values yielded a total carbon burial in vegetated habitats of $111 \mathrm{Tmol} \mathrm{C} \mathrm{y}^{-1}$. The total burial in unvegetated sediments was estimated to be $126 \mathrm{Tg} \mathrm{C} \mathrm{y}^{-1}$, resulting in a bottom-up estimate of total burial in the ocean of about $244 \mathrm{Tg} \mathrm{C}^{-1}$, two-fold higher than estimates of oceanic carbon burial that presently enter global carbon budgets. The organic carbon concentrations in vegetated marine sediments exceeds by 2 to 10 -fold those in shelf/deltaic sediments. Top-down recalculation of ocean sediment budgets to account for these, previously neglected, organic-rich sediments, yields a topdown carbon burial estimate of $216 \mathrm{Tg} \mathrm{C}^{-1}$, with vegetated coastal habitats contributing about $50 \%$. Even though vegetated carbon burial contributes about half of the total carbon burial in the ocean, burial represents a small fraction of the net production of these ecosystems, estimated at about $3388 \mathrm{Tg} \mathrm{C}^{-1}$, suggesting that bulk of the benthic net ecosystem production must support excess respiration in other compartments, such as unvegetated sediments and the coastal pelagic compartment. The total excess organic carbon available to be exported to the ocean is estimated at between 1126 to $3534 \mathrm{Tg} \mathrm{C} \mathrm{y}^{-1}$, the bulk of which must be respired in the open ocean. Widespread loss of vegetated coastal habitats must have reduced carbon burial in the ocean by about $30 \mathrm{Tg} \mathrm{Cy}^{-1}$, identifying the destruction of
\end{abstract}

Correspondence to: C. M. Duarte

(cduarte@uib.es) these ecosystems as an important loss of $\mathrm{CO}_{2}$ sink capacity in the biosphere.

\section{Introduction}

Oceanic carbon fluxes are believed to be dominated by microorganismal activity, as bacteria and microalgae are the dominant source of primary production and respiration in the ocean (e.g. Duarte and Cebrián, 1996; del Giorgio and Duarte, 2002). Marine ecosystems also include macrophytedominated communities, hereafter referred to as marine vegetation, in the coastal domain, including macroalgae, dominant in rocky shore, estuarine environments and coral reefs, and angiosperms, which are dominant in intertidal systems (mangroves in tropical regions and salt marshes in temperate ones) and seagrasses growing in sandy, and occasionally rocky sediments along the world's coasts (e.g. Alongi, 1998). Although vegetated habitats are acknowledged to be of major importance to sustain marine biodiversity (e.g. Duarte, 2001; Alongi, 2002), they are neglected from present accounts of the global ocean carbon cycle. The neglect of marine vegetation is possibly a consequence of the limited extent of marine vegetation, which cover only $<2 \%$ of the ocean surface (Duarte and Cebrián, 1996). Moreover, the area covered by marine vegetation is rapidly declining, as the area covered by seagrass meadows, mangrove forests and salt marshes has declined significantly over the past decades (Valiela et al., 2001; Duarte, 2002; Alongi, 2002; Green and Short, 2003; Brevik and Homburg, 2004; Duarte et al., 2005b).

However, previous analyses of the carbon cycling in ecosystems dominated by marine vegetation suggest that these may be important, as their global respiration is about 7 to $8 \mathrm{Pg} \mathrm{C} \mathrm{y}^{-1}$ (Middelburg et al., 2004) and, yet, they may account for an important fraction of carbon storage in the ocean

(C) 2005 Author(s). This work is licensed under a Creative Commons License. 
Table 1. Estimates of organic carbon burial rates in vegetated areas, derived from the geometric mean of a compilation of published reports of organic carbon burial and their relative contribution to burial in the coastal ocean and the global ocean. The estimates derived are compared to those derived from community mass balances (M.B.), estimated by correcting the estimates in Duarte and Cebrián (1996) for the revised area covered by the different communities used here.

\begin{tabular}{|c|c|c|c|c|c|c|c|}
\hline \multirow[t]{2}{*}{ Component } & & \multirow{2}{*}{$\begin{array}{r}\text { Area } \\
10^{12} \mathrm{~m}^{2}\end{array}$} & \multirow[t]{2}{*}{$\mathrm{g} \mathrm{C} \mathrm{m}^{-2} \mathrm{y}^{-1}$} & \multirow[t]{2}{*}{$\operatorname{Tg~}^{-1}$} & \multicolumn{3}{|c|}{$\operatorname{Tg} \mathrm{y}^{-1}$} \\
\hline & & & & & $\mathrm{N}$ & M.B. & Notes \\
\hline \multicolumn{8}{|l|}{ Vegetated habitats } \\
\hline & Mangroves & 0.2 & 139.0 & 23.6 & 27 & 17.0 & 1 \\
\hline & Salt Marsh & 0.4 & 151.0 & 60.4 & 96 & 70.0 & 2 \\
\hline & Seagrass & 0.3 & 83.0 & 27.4 & 5 & 44.0 & 3 \\
\hline Total vegetated habitats & & & & 111.4 & & 131.0 & \\
\hline \multicolumn{8}{|l|}{ Depositional areas } \\
\hline & Estuaries & 1.8 & 45.0 & 81.0 & 24 & & 4 \\
\hline & Shelf & 26.6 & 17.0 & 45.2 & 15 & & 5 \\
\hline \multirow[t]{2}{*}{ Total coastal burial } & & & & 237.6 & & & \\
\hline & $\%$ vegetated habitats & & & 46.9 & & & \\
\hline Deep sea burial & & & & 6.0 & & & 6 \\
\hline \multirow[t]{2}{*}{ Total oceanic burial } & & & & 243.6 & & & \\
\hline & $\%$ vegetated habitats & & & 45.7 & & & \\
\hline
\end{tabular}

Notes: 1. Area covered from Valiela et al. (2001), organic burial data from Chmura et al. (2003); 2. Area covered from Woodwell et al. (1973), organic burial data from Chmura et al. (2003); 3. Area covered calculated from original extent of seagrass and reported fraction relative longterm decline rates (Green and Short, 2003; Duarte et al., 2005b), organic burial data from Gacia et al., 2002; Romero et al., 1994; Mateo et al., 1997, 2005, and Barron et al., 2004; 4. Area covered from Costanza et al. (1997), organic burial data from Heip et al. (1995) and Widdows et al. (2004); 5. Area covered from Costanza et al. (1997) assuming that depositional areas cover 10\% of the shelf area, organic burial data from Middelburg et al. (1997a); 6. Berner (1982).

(Duarte and Cebrián, 1996; Jennerjahn and Ittekkot, 2002; Chmura et al., 2003). Further, analyses of the carbon budgets of marine vegetated benthic communities suggest that they export significant amounts of organic carbon to adjacent ecosystems and also store vast amounts of organic carbon in the sediments (Duarte and Cebrián, 1996; Jennerjahn and Ittekkot, 2002; Chmura et al., 2003; Brevik and Homburg, 2004). Moreover, their high burial rates can be sustained over millennia (Mateo et al., 1997; Brevik and Homburg, 2004). Marine vegetation turns over very slowly (Smith, 1981), as it is often dominated by long-lived organisms such as mangroves (decades, Tomlinson, 1994) and seagrasses (years to decades, Hemminga and Duarte, 2000), so that despite contributing only $10 \%$ of the primary production of the ocean (Smith, 1981; Duarte and Cebrián, 1996), marine vegetation holds a significant fraction of the autotrophic biomass therein (Smith, 1981). The view that the reduced extent of marine vegetation relative to the size of the ocean renders them irrelevant to global cycles can be, therefore, challenged (Smith, 1981).

Here we assess the role of marine vegetation in carbon fluxes in the coastal ocean and the consequences of the widespread destruction of these habitats for the marine organic carbon cycle. We first estimate carbon burial in vegetated habitats following two approaches, a bottom-up approach derived from upscaling individual estimates of car- bon burial in vegetated habitats to the global level, and a top-down approach derived from considerations of the global sediment balance (Berner, 1982). We then construct a carbon budget for the coastal ocean, including carbon burial, respiration (from Middelburg et al., 2005), and gross primary production (from Duarte and Cebrián, 1996), and examine, using mass balance considerations, the possible organic export from vegetated habitats to the open ocean and the impact of destruction of marginal coastal habitats where marine vegetation dominates on the carbon budget of the global ocean.

\section{Burial}

We searched the published literature for estimates of carbon burial in vegetated habitats to derive estimates of average carbon burial of these communities. Because of the skewed nature of the resulting data sets, the geometric mean was used to characterise the central tendency of carbon burial in these communities (Table 1). Whereas the coverage of estimates of organic carbon burial is reasonable $(\mathrm{N}>25)$ for both mangroves and salt marshes, that for other communities is small, as only 5 estimates were available for seagrass meadows (Table 1). The data compiled identified mangroves and salt marshes as important sites for carbon burial, at rates twice as high as those for seagrass meadows (Fig. 1, Table 1). Up-scaling of individual burial estimates to the global 


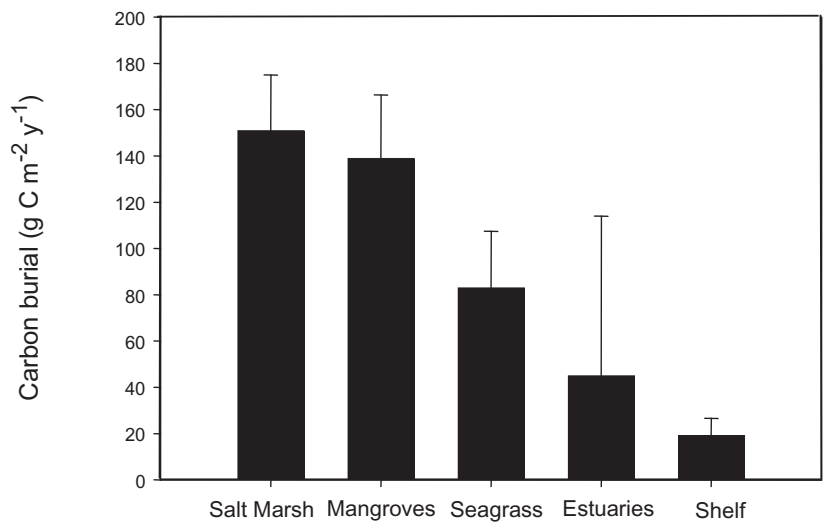

Fig. 1. Average $( \pm \mathrm{SE})$ carbon burial rates in different coastal ecosystems. Data sources in Table 1.

scale yields a total carbon burial in vegetated habitats of $111 \mathrm{Tmol} \mathrm{Cy}^{-1}$ (Table 1). This estimate is remarkably close to the estimate of carbon storage rates in vegetated habitats of $131 \mathrm{Tmol} \mathrm{C} \mathrm{y}{ }^{-1}$ derived in the past by up-scaling carbon budgets for marine vegetation communities compiled (Table 1, Duarte and Cebrián, 1996), therefore providing confidence on the robustness of these estimates.

The agreement between bottom-up approaches based on direct burial estimates with those derived from carbon budgets for the vegetation implies that a significant, although variable, proportion of the carbon buried should be of autochthonous origin, which is consistent with published evidence suggesting a significant contribution of autochthonous organic carbon in salt marsh (Ember et al., 1997; Middelburg et al., 1997b) mangrove (Jennerjahn and Ittekkot, 2002; Bouillon et al., 2004; Kennedy et al., 2004) and seagrass (Gacia et al., 2002; Kennedy et al., 2004; Holmer et al., 2004) sediments. Present estimates of the carbon burial in the ocean, as components of the global carbon budget (126$160 \mathrm{Tg} \mathrm{y}^{-1}$, Berner, 1982; Hedges and Keil, 1995; IPPC, 2001), ignore vegetated coastal habitats and must, therefore, be revised upwards.

The estimate of burial in the ocean that enters present global carbon budgets is, however, derived from top-down considerations of the total sediment budget of the ocean (Berner, 1982) and cannot, therefore, be readily compared to the bottom-up estimates used above. Hence, we also estimated the contribution of unvegetated sediments in estuaries and shelf and deltaic environments. The data set on direct estimates of burial in estuarine (Heip et al., 1995; Widdows et al., 2004) and shelf sediments (Middelburg et al., 1997a) encompassed a total of 39 observations, with geometric average rates in these environments about one third of those for vegetated habitats (Fig. 1, Table 1). Up-scaling burial in these environments to the global scale is, however, not trivial as the estimates of burial in these dynamic environments are biased towards depositional basins (Middelburg et al., 1997a).

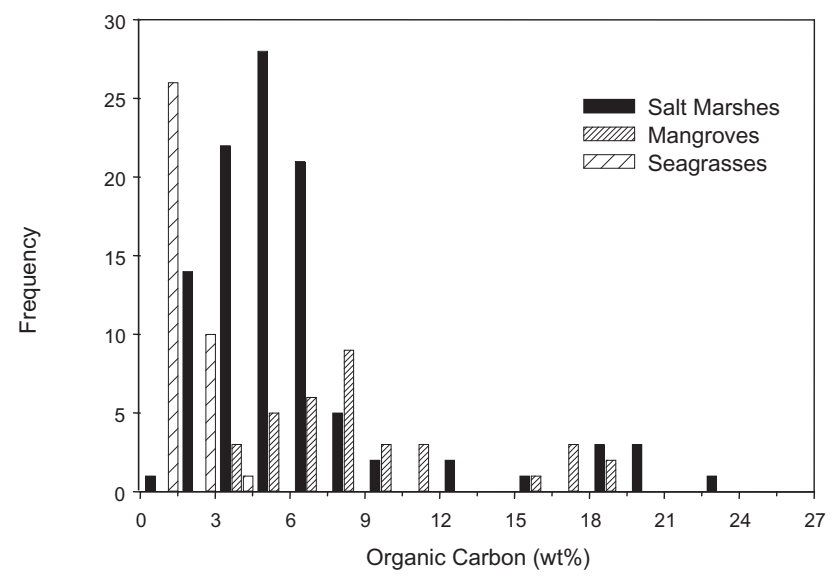

Fig. 2. Frequency distribution of organic carbon content in salt marsh, mangrove and seagrass sediments. Data sources in Table 2.

We therefore, following assessments of the extent of shelf depositional basins (de Haas et al., 2002), assumed that these basins represent only $10 \%$ of the shelf area (Table 1). The corresponding geometric estimates of burial in unvegetated estuarine and shelf sediments amounts, when scaled to this area, to 81 and $45 \mathrm{Tg} \mathrm{C}^{-1}$, respectively (Table 1 ). The total burial in unvegetated sediments $\left(126 \mathrm{Tg} \mathrm{C}^{-1}\right)$ is very similar to Berner's $130 \mathrm{Tg} \mathrm{C} \mathrm{y}^{-1}$ estimate for deltaic-shelf sediments and somewhat below the Hedges and Keil (1995) revised estimate of burial in the coastal ocean $\left(160 \mathrm{Tg} \mathrm{C}^{-1}\right)$. The resulting bottom-up estimate of total burial in the ocean adds to $244 \mathrm{Tg} \mathrm{C}^{-1}$ (Table 1), which is two-fold higher than estimates of oceanic carbon burial that presently enter global carbon budgets and implies, therefore, that the ocean is, because of the major - but previously neglected - contribution of vegetated habitats, a greater carbon sink than hitherto acknowledged. These calculations indicate that vegetated marine habitats, which only cover $<2 \%$ of the ocean surface, contribute close to half of the carbon burial in the coastal and global, ocean at present (Table 1).

The significance and consequences of the major deviation between the Berner (1982) estimates and that derived using a bottom-up approach here for our understanding of the global carbon cycle implies that the basis for this difference must be identified. The Berner (1982) calculation is based on a global sediment input of $18000 \mathrm{Tg} \mathrm{y}^{-1}$ to the ocean, assuming that $700 \mathrm{Tg}$ is deposited in deep ocean basins and that all of the remaining materials are deposited in the coastal ocean, i.e. in deltaic-shelf environments. Based on an organic carbon content of $0.75 \%$, he derived a coastal organic carbon burial of $130 \mathrm{Tg} \mathrm{C}{ }^{-1}$. Whereas the total sediment input to the ocean is a reasonably well-constrained figure $\left(20000 \mathrm{Tg} \mathrm{y}^{-1}\right.$, Milliman and Syvitski, 1992; Hay, 1998), top-down estimates of organic carbon burial depend on where the sedimentation occurs because carbon contents differ (Berner, 1982; Hedges and Keil, 1995). Berner (1982) used an organic 
Table 2. The average percent organic carbon (Corg, \%) of vegetated and unvegetated sediments in the coastal ocean and the estimate of the organic carbon burial resulting from burial of the sediment load of $20000 \mathrm{Tg} \mathrm{y}^{-1}$ (Milliman and Syvitski, 1992; Hay, 1998) entering the coastal ocean in these habitats.

\begin{tabular}{|c|c|c|c|c|c|c|c|}
\hline & & Burial Tg $\mathrm{Cy}^{-1}$ & Corg $(\%)$ & $\mathrm{Tg}$ sediment & $\%$ sediment & $\%$ C-burial & Notes \\
\hline \multicolumn{8}{|l|}{ Vegetated habitats } \\
\hline & Mangroves & 23.6 & 8.5 & 278 & 1.4 & 10.9 & 1 \\
\hline & Salt Marsh & 60.4 & 5.4 & 1119 & 5.6 & 27.9 & 2 \\
\hline & Seagrass & 27.4 & 0.7 & 3914 & 19.6 & 12.7 & 3 \\
\hline Total vegetated habitats & & 111.4 & & 5310 & 26.6 & 51.5 & \\
\hline Depositional areas & & 98.9 & 0.75 & 13190 & 65.9 & 45.7 & 4 \\
\hline Total coastal burial & & 210.3 & & 18500 & 92.5 & 97.2 & \\
\hline Deep sea burial & & 6.0 & 0.4 & 1500 & 7.5 & 2.8 & 5 \\
\hline Total oceanic burial & & 216.3 & & 20000 & & & \\
\hline
\end{tabular}

Notes: 1. Organic carbon contents from Chmura et al. (2003); 2. Organic carbon contents from Chmura et al. (2003); 3. Organic carbon contents estimated based on Gacia et al. (2002), Holmer et al. (2004), Kennedy et al. (2004), Duarte et al. (2005a) and unpublished data. 4. Organic carbon content of $0.75 \%$ is assumed and sediment burial is calculated by difference; 5 . Organic carbon content is assumed (e.g. see Berner, 1982).

carbon content of $0.75 \%$ that is representative of the shelf and deltaic sediments, where the deposition was supposed to occur. Hedges and Keil (1995) argued that two-third of the river particulate accumulated in deltaic sediment with an organic content of $0.7 \%$ and one-third in shelf and upper slope sediment with $1.5 \%$ organic carbon and revised the burial estimate upward to $160 \mathrm{Tg} \mathrm{C}^{-1}$. These studies ignore the carbon-rich deposits of marine vegetated systems. Indeed, a compilation of organic carbon concentrations in vegetated marine sediments indicates that these are particularly high for mangroves and salt marshes, holding, 2 to 10-fold greater concentrations than shelf and deltaic sediment do (Fig. 2, Table 2). Consequently, the top-down estimate of burial in the ocean can be corrected, using a similar approach to that of Berner (1982). By combining the bottom-up estimates for carbon burial in vegetated sediments and deep-sea sediments with estimates of their organic carbon content, we can derive sediment accumulation in these habitats. The difference between particle delivery to the ocean and the sum of vegetated and deep-sea sedimentation can then be attributed to unvegetated coastal deposition. These calculations indicate that $26 \%$ of the sediment acumulate in vegetated systems and only about $8 \%$ in the deep-sea, the remaining $65 \%$ accumulates in estuaries, deltaic, shelf and upper slope environments. Following Berner (1982) we combined a conservative organic carbon content of $0.75 \%$ for unvegetated coastal sediments with a sediment accumulation rate of about $13000 \mathrm{Tg}$ and derived an unvegetated coastal burial rate of $99 \mathrm{Tg} \mathrm{C}^{-1}$, somewhat lower than the sum of estuarine and shelf carbon burial reported in Table $1\left(126 \mathrm{Tg} \mathrm{C}^{-1}\right)$. The total top-down carbon burial estimate obtained was then $210 \mathrm{Tg} \mathrm{C} \mathrm{y}^{-1}(\mathrm{Ta}-$ ble 2), reasonably close to that of $244 \mathrm{Tg} \mathrm{C} \mathrm{y}^{-1}$ (Table 1) derived from the bottom-up approach described above, with vegetated coastal habitats contributing about $50 \%$ in both ap- proaches (Tables 1, 2). Hence, the conclusion that organic carbon burial in the ocean exceeds the estimate of burial in the ocean that enters present global carbon budgets almost by a factor two is, as supported both by bottom-up and top-down approaches, a robust one.

A further top-down constraint on the possible $\mathrm{C}$ burial in shallow-water coastal ecosystems is the fact that a very high burial rate sustained over a long time span may raise the sea floor above the mean sea level. To assess whether this may constrain the estimates presented here we calculated the accretion rate implicit in our burial estimates by combining the $\mathrm{C}$ burial rate (Table 1) with the organic $\mathrm{C}$ content of the sediments (Table 2), assuming a bulk sediment density of $1 \mathrm{~g} \mathrm{~cm}^{-3}$. The estimated accretion rates ranged between $1.6 \mathrm{~mm} \mathrm{yr}^{-1}$ for mangrove forests to a maximum of about $12 \mathrm{~mm} \mathrm{yr}^{-1}$ for seagrass meadows. These numbers are consistent with published estimates of sediment accretion rates across these habitats, with reported accretion rates for mangrove forests up to $8 \mathrm{~mm} \mathrm{yr}^{-1}$ (Woodroffe, 1992) and seagrass accretion rates ranging from 0.2 to $40 \mathrm{~mm} \mathrm{yr}^{-1}$ (Mateo et al., 1997; Walker and Wolkerling, 1998; Gacia et al., 2002). High sediment accretion in seagrass meadows does not pose a problem a priori, as these grow deeper than mangroves and salt marshes, and high sediment accretion in salt marsh and mangrove areas is partially compensated by subsidence (e.g. Callaway et al., 1996; Patrick and Delaune, 1990; Woodroffe, 1992).

The estimates of $\mathrm{C}$ burial in vegetated coastal habitats derived here should be considered, however, conservative, as deposition is only considered in angiosperm-dominated habitats. Whereas macroalgae often grow in rocky shores, where substantial sedimentation rates are unlikely, many of them can also thrive in sandy and muddy bottom where $\mathrm{C}$ may be buried. However, the possibility of $\mathrm{C}$ burial in macroalgal 
Table 3. The metabolic balance of the benthic coastal communities, as represented by the respiration rates ( $\mathrm{R}$, average and global values from Middelburg et al., 2005), gross primary production (GPP), computed using average values from net primary production and autotrophic respiration estimates in Duarte and Cebrián (1996) and GPP estimates in Gattuso et al. (1998) for coral reefs, upscaled to the global coastal ocean using the surface areas covered by the communities reported in Table 1, and Duarte and Cebrián (1996) for macroalgae and microphytobenthos; and the net ecosystem production (NEP=GPP-R) for these ecosystems.

\begin{tabular}{|c|c|c|c|c|c|c|c|c|}
\hline Component & & $\begin{array}{r}\text { Area } \\
10^{12} \mathrm{~m}^{2}\end{array}$ & $\mathrm{~g} \mathrm{C} \mathrm{m}^{-2} \mathrm{y}^{-1}$ & $\begin{array}{c}\text { Global R } \\
\operatorname{Tg~y}^{-1}\end{array}$ & $\mathrm{~g} \mathrm{C} \mathrm{m}^{-2} \mathrm{y}^{-1}$ & $\begin{array}{r}\text { Global GPP } \\
\mathrm{Tg} \mathrm{y}^{-1}\end{array}$ & $\mathrm{~g} \mathrm{C} \mathrm{m}^{-2} \mathrm{y}^{-1}$ & $\begin{array}{r}\text { Global NEP } \\
\operatorname{Tg~y}^{-1}\end{array}$ \\
\hline \multicolumn{9}{|l|}{ Vegetated habitats } \\
\hline & Mangroves & 0.2 & 1866 & 373 & 2087 & 417 & 221 & 44 \\
\hline & Salt Marsh & 0.4 & 2010 & 804 & 3595 & 1438 & 1585 & 634 \\
\hline & Seagrass & 0.3 & 692 & 228 & 1903 & 628 & 1211 & 400 \\
\hline & Macroalgae & 1.4 & 2116 & 2962 & 3702 & 5183 & 1587 & 2221 \\
\hline & Coral Reefs & 0.6 & 1572 & 943 & 1720 & 1032 & 148 & 89 \\
\hline Total vegetated habitats & & & & 5310 & & 8698 & & 3388 \\
\hline Unvegetated sediments & & 23.9 & 83 & 1992 & 67.9 & 1622 & -15 & -370 \\
\hline Global benthic coastal ocean & & & & 7302 & & 10320 & & 3018 \\
\hline & $\%$ vegetated habitats & & & 73 & & 84.3 & & \\
\hline
\end{tabular}

beds has not been studied and, therefore, cannot be included in this assessment.

\section{Metabolism of vegetated habitats and the organic car- bon budget of the ocean}

Estimates of respiration $(\mathrm{R})$ in vegetated habitats have been recently compiled using a dual top-down and bottom-up approach as done here (Middelburg et al., 2005). The resulting estimate of $\mathrm{R}$ in vegetated habitats was $5310 \mathrm{Tg} \mathrm{C}^{-1}$, with a particularly high contribution by macroalgae (Table 3 ). The important contribution of macrophytes to the respiration in benthic vegetated habitats (Middelburg et al., 2005) is in contrast with respiration in other oceanic habitats, which is dominated by bacteria (del Giorgio and Williams, 2005). The gross primary production (GPP) rates of vegetated habitats are quite high (Duarte and Cebrián, 1996) yielding, when scaled to the global extent of these communities, a GPP of $8698 \mathrm{Tg} \mathrm{C} \mathrm{y}^{-1}$. These estimates yield a positive metabolic balance $(\mathrm{NCP}=\mathrm{GPP}-\mathrm{R}>0)$ for vegetated habitats estimated at about $3388 \mathrm{Tg} \mathrm{C} \mathrm{y}^{-1}$ (Table 3), where macroalgae, seagrass beds and salt marshes are the dominant contributors to excess production. These values need to be increased by the GPP and R of benthic unvegetated and estuarine systems, which are estimated to be net heterotrophic at the global scale (Table 3), to yield a NCP for benthic coastal communities of $3018 \mathrm{Tg} \mathrm{C} \mathrm{y}^{-1}$ (Table 3).

The excess production of the benthic compartment has two possible fates, to be stored in sediments contributing to burial therein or to be exported for use in the pelagic compartment. As the total organic carbon burial rate in the coastal ocean is about $9 \%$ of the calculated NCP figure, it follows that the bulk ( $>91 \%$, as some of the buried material is of terrestrial origin), of the benthic net ecosystem production (NEP) must either be exported to the open ocean or support respiration in the pelagic compartment. The pelagic compartment of coastal ecosystems is often heterotrophic (Smith and Hollibaugh, 1983; Duarte et al., 2004; Lucea et al., 2005), and a NEP range for the pelagic coastal ocean of $-2304 \mathrm{Tg} \mathrm{C}^{-1}$ to $104 \mathrm{Tg} \mathrm{C}^{-1}$ has been proposed (Robinson and Williams, 2005). The excess benthic NEP that must be exported to support respiration in the global ocean can be calculated as,

Export $=$ Benthic NEP + Terrestrial inputs - Burial

+ Pelagic coastal NEP

which provided a terrestrial input of organic carbon of $650 \mathrm{Tg} \mathrm{C} \mathrm{y}^{-1}$ (Duarte and Cebrián, 1996), yields an organic carbon export from the coastal to the open ocean ranging between 769 to $3177 \mathrm{Tg} \mathrm{C} \mathrm{y}^{-1}$, with this range depending on the uncertainty about the pelagic coastal NEP (Fig. 3). The estimated coastal export of 1126 to $3534 \mathrm{Tg} \mathrm{C} \mathrm{y}^{-1}$ is then available to be used - or buried - in the open ocean. As burial in the open ocean is estimated at a much lower figure of $6 \mathrm{Tg} \mathrm{C}^{-1}$ (Table 1), it follows that essentially all of the organic carbon received from the coastal ocean must be respired in the open ocean. This export, which is of the same order as the inputs necessary to balance the calculated net heterotrophy of the open ocean (Duarte and Agustí, 1998), would contribute, as proposed in the past (Duarte et al., 1999), to drive the open ocean to a net heterotrophic status (Duarte and Agustí, 1998; del Giorgio and Duarte, 2002). Most past estimates of the organic export from the coastal to the open ocean are below the figure above (Liu et al., 2002; Ducklow and McCallister, 2005), likely because these estimates neglected, again, the contribution of vegetated habitats. Indeed, more encompasing accounts (del Giorgio and Duarte, 2002) cover the range of export estimates derived above. 


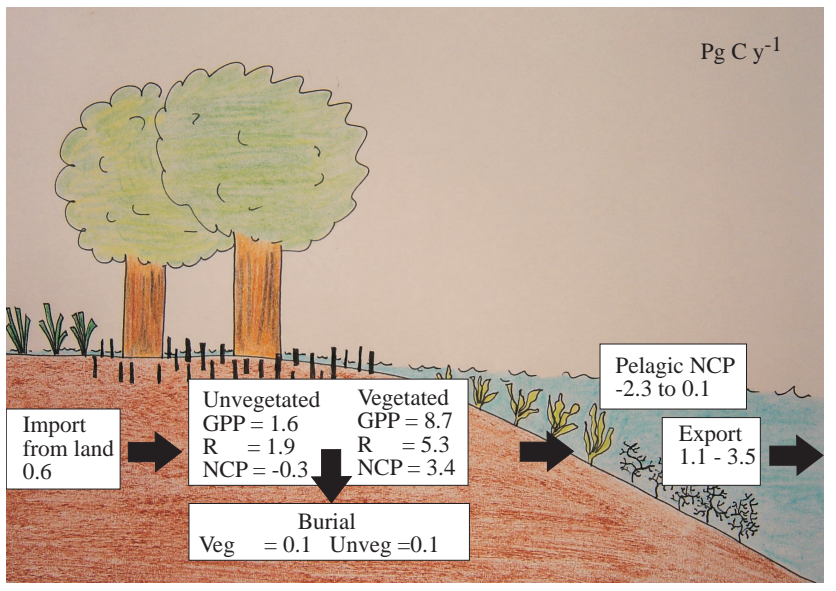

Fig. 3. Summary of the organic carbon budget (units $\mathrm{Gt} \mathrm{C}^{-1}$ ) of the global coastal ocean. $\mathrm{NCP}=\mathrm{Net}$ community production. $\mathrm{GPP}=$ Gross Primary Production. $\mathrm{R}=$ Respiration.

\section{Destruction of marine vegetated habitats and oceanic carbon burial}

The preceding analysis portrays vegetated marine habitats as critical sites for carbon burial, production and respiration as well as to subsidise the metabolism of the open ocean. Mangrove and seagrass habitats are, however, experiencing widespread destruction due to multiple causes, involving logging, land reclamation and deforestation for mangroves (Valiela et al., 2001; Alongi, 2002), eutrophication, siltation and coastline alteration for seagrasses (cf. Duarte, 2002; Short and Green, 2003; Duarte et al., 2005b) and coastal erosion, filling, dyking, and conversion to aquaculture ponds for salt marshes (Adam, 2002; Brevik and Homburg, 2004). The rates of habitat destruction for these communities are mounting, with about $35 \%$ to $50 \%$ of the world mangrove area destroyed, mostly since World War II (Valiela et al., 2001; Alongi, 2002), and an estimated loss of $18 \%$ of the documented seagrass area over the last two decades (Green and Short, 2003), which is likely to be an underestimate due to poor coverage for some areas. These losses render seagrass meadows and mangrove forests as some of the world's most threatened habitats, with multi-decadal average annual rates of decline of $2 \% \mathrm{y}^{-1}$ for mangroves (Valiela et al., 1998) and $>1 \% \mathrm{y}^{-1}$ for seagrasses, (Duarte, 2002; Short and Green, 2003; Duarte et al., 2005b).

Whereas the calculations of the important role of these habitats in carbon burial in the ocean were based on the estimated extant area they cover (Table 1), the great rates of decline these habitat experience suggests that their role in carbon burial in the ocean should have been far larger than that calculated at present. An estimate of the historical carbon burial in the coastal zone can be calculated, using the two approaches derived above. The bottom-up calculation (Table 1), assumes rates similar to those presently observed extended to an undisturbed area covered by mangroves and seagrass of $0.2510^{12} \mathrm{~m}^{2}$ and $0.5-0.610^{12} \mathrm{~m}^{2}$ (Duarte and Cebrián, 1996; Green and Short, 2003), respectively. These calculations derived a carbon burial in vegetated carbon burials previous to anthropogenic disturbance of $140 \mathrm{Tg} \mathrm{Cy}^{-1}$, or $25 \%$ higher than the present estimate. This estimate represents an underestimate, as it does not consider losses of salt-marshes (e.g. Adam, 2002; Brevik and Homburg, 2004), for which no global estimate is currently available. The topdown rationale provided above suggests that this loss would correspond to the difference in carbon content of the sediment being buried (Berner, 1982). A difference of $1 \% \mathrm{C}$ corresponds to a loss in organic carbon burial capacity due to loss of vegetated habitat of about 30 to $50 \mathrm{Tg} \mathrm{C} \mathrm{y}{ }^{-1}$, or 13 to $25 \%$ of the present burial in the global ocean. Although these losses are sizeable, they cannot be resolved through budgetary exercises such as those used here, which involve uncertainties about the global burial figures in excess of the $25 \%$ estimate.

The decline in coastal burial derived from the loss of vegetated habitats is compounded with the reduced delivery of terrestrial sediments to the ocean from increased sediment retention in reservoirs, which have been estimated to reduce global sediment delivery to the oceans by about $30 \%$ (Vörösmarty et al., 2003). Hence, the loss of benthic vegetated habitats have reduced $\mathrm{C}$ burial in vegetated habitats by about $25 \%$, and the reduced sediment delivery to the ocean, formerly deposited along with organic carbon in the coastal ocean, has reduced oceanic $\mathrm{C}$ burial by a further $30 \%$ of the total $\mathrm{C}$ burial, suggesting a combined possible loss of carbon burial in the ocean of as much as $50 \%$ of the pre-disturbance rate.

\section{Conclusions}

The results presented confirm that vegetated coastal habitats, including seagrass meadows, mangrove forests and salt marshes are hot spots for carbon burial in the ocean. The significant of mangrove and salt marshes has been recently raised on the basis of bottom-up approaches (Jennerjahn and Ittekkot, 2002; Chmura et al., 2003), and an important role of vegetated habitats had been suggested on the basis of community carbon budgets (Duarte and Cebrián, 1996). Here we show that use of bottom-up scaling of direct burial estimates, community carbon budgets, and top-down examinations that consider, for the first time, the enhanced organic carbon concentration of vegetated coastal sediments converge to estimate organic carbon burial in the coastal ocean at 210$244 \mathrm{Tg} \mathrm{C} \mathrm{y}^{-1}$, almost twice as high as that presently considered in drawing the global carbon budget (IPCC, 2001). This discrepancy is due to the neglect in previous assessments of vegetated coastal habitats, which despite encompassing $<2 \%$ of the ocean surface contribute close to half of the carbon burial in the coastal and global ocean at present. Hence, our 
analysis identifies vegetated coastal habitats as important, but previously neglected, sites for $\mathrm{CO}_{2}$ sequestration. However, even this upward revised estimate of organic carbon burial can not accommodate for the removal of anthropogenic carbon dioxide from the atmosphere (Berner, 1992).

Our assessment depicts, in agreement with previous assessments (e.g. Duarte and Cebrián, 1996; Gattuso et al., 1998), vegetated coastal habitats to be net autotrophic ecosystems. Despite the important size of organic carbon burial in these habitats, our results suggest that only $5 \%$ of our estimated $2661 \mathrm{Tg} \mathrm{C} \mathrm{y}^{-1}$ excess production (NCP) of benthic coastal habitats meet a fate in burial. The bulk of the net production of vegetated coastal habitats, must be exported at a rate estimated at between 769 to $3177 \mathrm{Tg} \mathrm{C} \mathrm{y}^{-1}$, to partially support the high respiratory requirements of open ocean ecosystems (del Giorgio and Duarte, 2002; Arístegui et al., 2004), helping explain the tendency of unproductive oceanic ecosystems to be net heterotrophic (Duarte et al., 1998, 1999; del Giorgio et al., 2002). The uncertainty about the extent of vegetated coastal habitats is a main source of uncertainly about our estimates. This is particularly severe for submerged macrophytes, particularly seagrass meadows, where present estimates of area cover are derived from consideration of the habitat requirements of seagrass beds, rather than observations (Green and Short, 2003). Whereas the observational basis is much better for salt marshes and mangroves, which can be delineated from space, the rapid loss of these habitats also render estimates of global area covered highly unstable. Realisation of the important role of coastal vegetated habitats on the marine $\mathrm{C}$ cycle should provide the impetus needed to improve present estimates of the area these habitats cover and how this is changing.

The important role of vegetated coastal habitats in the ocean carbon budget is, however, eroded by the high losses experienced by these ecosystems, where between $1 / 3$ and $1 / 2$ of the original area covered of seagrass meadows and mangrove forests and a large, but unknown fraction of the global salt marsh cover have been lost by anthropogenic destruction of these habitat. More than $25 \%$ of the $\mathrm{CO}_{2}$ sink capacity of these ecosystems has been lost, and their capacity to support the metabolism of open ocean ecosystems must have declined accordingly. Besides the large impact on biodiversity, these losses represent an important loss of $\mathrm{CO}_{2}$ sink capacity. The important consequences of the destruction of marine vegetated habitats on the oceanic carbon budget adds to the dramatic consequences these losses have on local biodiversity (Adam, 2002; Alongi, 2002; Duarte, 2002) to conform an environmental crisis that requires immediate attention.

Acknowledgements. This research is a contribution to project EUROTROPH, funded by the European Commission (project EUROTROPH, EVK3-CT-2000-00040, ref. REN2001-4977-E) and the "Integrating the aquatic with the terrestrial component of the global carbon budget" Working Group supported by the National Center for Ecological Analysis and Synthesis, a Centre supported by NSF (Grant \#DEB-94-21535), the University of
California at Santa Barbara, and the State of California. We thank S. Smith, S. Bouillon, and an anonymous reviewer for useful suggestions, and G. Duarte for art work. C. M. Duarte was supported by a sabbatical fellowship from the Spanish Ministry of Education and Science. This is publication 3503 NIOO-KNAW Netherlands Institute of Ecology.

Edited by: C. Heinze

\section{References}

Adam, P.: Saltmarshes in a time of change, Environ. Conserv., 29, 39-61, 2002.

Alongi, D. M.: Coastal Ecosystem Processes, New York, USA, CRC Press, 419, 1998.

Alongi, D. M.: Present state and future of the world's mangrove forests, Environ. Conserv., 29, 331-349, 2002.

Barrón, C., Marbà, N., Terrados, J., Kennedy, H., and Duarte, C. M.: Community metabolism and carbon budget along a gradient of seagrass (Cymodocea nodosa) colonization, Limnol. Oceanogr., 49, 1642-1651, 2004.

Berner, R. A.: Burial of organic carbon and pyrite sulfur in the modern ocean: Its geochemical and environmental significance, Am. J. Sci., 282, 451-473, 1982.

Berner, R. A.: Comments on the role of marine sediment burial as a repository for anthropogenic $\mathrm{CO}_{2}$, Global Biogeochem. Cycles, 6, 1-2, 1992.

Brevik, E. C. and Homburg, J. A.: A 5000 year record of carbon sequestration from a coastal lagoon and wetland complex, Southern California, USA, Catena, 57, 221-232, 2004.

Bouillon, S., Moens, T., Koedam, N., Dahdouh-Guebas, F., Bayens, W., and Dehairs, F.: Variability in the origin of carbon substrates for bacterial communities in mangrove sediments, FEMS Microb. Ecol., 49, 171-179, 2004.

Callaway, J. C., DeLaune, R. D., and Patrick, W. H.: Chernobyl Cs137 used to determine sediment accretion rates at selected northern European coastal wetlands, Limnol. Oceanogr., 41, 444-450, 1996.

Chmura, G. L., Anisfeld, S. C., Cahoon, D. R., and Lynch, J. C.: Global carbon sequestration in tidal, saline wetland soils, Global Biogeochem. Cycles, 17, doi:10.1029/2002GB001917, 2003.

Costanza, R., d'Arge, R., De Groot, R., Fraber, S., Grasso, M., Hannon, B., Limburg, K., Naeem, S., O’Neill, R. V., Paruelo, J., Raskin, R. G., Sutton, P., and Van den Belt, M.: The value of the world's ecosystem services and natural capital, Nature, 387, 253-260, 1997.

De Haas, H., van Weering, T. C. E., and de Stigter, H.: Organic carbon in shelf seas: sinks or sources, processes and products, Continental Shelf Res., 22, 691-717, 2002.

del Giorgio, P. A. and Duarte, C. M.: Respiration in the open ocean, Nature, 420, 379-384, 2002.

del Giorgio, P. A. and Williams, P. J. le B.: Respiration in aquatic ecosystems, Oxford Univ. Press, 2005.

Duarte, C. M.: Seagrass Ecosystems, In: Encyclopedia of biodiversity, edited by: Levin, S. L., Academic Press, San Diego, 5, 254-268, 2001.

Duarte, C. M.: The future of seagrass meadows, Environ. Conserv., 29, 192-206, 2002. 
Duarte, C. M. and Agustí, S.: The $\mathrm{CO} 2$ balance of unproductive aquatic ecosystems, Science, 281, 234-236, 1998.

Duarte, C. M. and Cebrián, J.: The fate of marine autotrophic production, Limnol. Oceanogr., 41, 1758-1766, 1996.

Duarte, C. M., Agustí S., Cole, J. J., and del Giorgio, P. A.: Is the oligotrophic ocean heterotrophic?, Science, 284, 1735, 1999.

Duarte, C. M., Agustí, S., and Vaqué, D.: Controls on planktonic metabolism in the Bay of Blanes, north-western Mediterranean litoral, Limnol. Oceanogr., 49, 2162-2170, 2004.

Duarte, C. M., Holmer, M., and Marbà, N.: Plant-microbe interactions in seagrass meadows, In: Interactions between macro- and microrganisms in marine sediments, edited by: Kristensen, E., Kotska, J. E., Haese, R. H., AGU Coastal and Estuarine Studies, 2005a.

Duarte, C. M., Borum, J., Short, F. T., and Walker, D. I.: Seagrass Ecosystems: Their Global Status and Prospects, In: Aquatic Ecosystems: Trends and Global Prospects, edited by: Polunin, N. V. C., Cambridge Univ. Press, 2005b.

Ducklow, H. W. and McCallister, S. L.: The biogeochemistry of carbon dioxide in the coastal oceans, In: The Sea, vol. 13: The Global Coastal Ocean-Multi-scale Interdisciplinary Processes, edited by: Robinson, A. R. and Brink, K., Harvard Univ. Press, 2004.

Ember, L. M., Williams, D. F., and Morris, J. T.: Processes that influence carbon isotopic variations in salt marsh sediments, Mar. Ecol. Prog. Ser., 36m, 33-42, 1987.

Gacia, E., Duarte, C. M., and Middelburg, J. J.: Carbon and nutrient deposition in the Mediterranean seagrass (Posidonia oceanica), Limnol. Oceanogr., 47, 23-32, 2002.

Green, E. P. and Short, F. T.: World Atlas of Seagrasses, California University Press, 310, 2003.

Hay, W. H.: Detrital sediment fluxes from continents to ocean, Chem. Geol., 145, 287-323, 1998.

Hedges, J. I. and Keil, R. G.: Sedimentary organic matter preservation: an assessment and speculative synthesis, Mar. Chem., 49, 81-115, 1995.

Heip, C. H. R., Goosen, N. K., Herman, P. M. J., Kromkamp, J., Middelburg, J. J., and Soetaert, K.: Production and consumption of biological particles in temperate tidal estuaries, Oceanogr. Mar. Biol. Ann. Rev., 33, 1-150, 1995.

Holmer, M., Duarte, C. M., Boschker, H. T. S., and Barrón, C.: Carbon cycling and bacterial carbon sources in pristine and impacted Mediterranean seagrass sediments, Aquat. Microb. Ecol., 36, 227-237, 2004.

IPCC: The carbon cycle and atmospheric carbon dioxide, 183-237, In: IPCC, Climate Change 2001, Cambridge Univ. Press, Cambridge, 2001.

Jennerjahn, T. C. and Ittekkot, V.: Relevance of mangroves for the production and deposition of organic matter along tropical continental margins, Naturwissenschaften, 89, 23-30, 2002.

Kennedy, H., Gacia, E., Kennedy, D. P., Papadimitriou, S., and Duarte, C. M.: Organic carbon sources to SE Asian coastal sediments, Estuarine Coastal Shel Sci., 60, 59-68, 2004.

Liu, J.-K., Iseki, K., and Chao, S.-Y.: Continental margin carbon fluxes In: The changing ocean carbon cycle, edited by: Hanson, R. B., Ducklow, H. W., and Field, J. G., Cambridge Univ. Press, 186-239, 2002.

Lucea, A., Duarte, C. M., Agustí, S., and Kennedy, H.: Nutrient dynamics and ecosystem metabolism in the Bay of Blanes (NW
Mediterranean), Biogeochemistry, in press, 2005.

Mateo, M. A., Romero, J., Perez, M., Littler, M. M., and Littler, D. S.: Dynamics of millenary organic deposits resulting from the growth of the Mediterranean seagrass Posidonia oceanica, Estuar. Coast. Shelf Sci., 44, 103-110, 1997.

Mateo, M. A., Cebrián, J., Dunton, K., and Mutchler, T.: Carbon flux in seagrass ecosystems, In: Seagrass Biology and Ecology, edited by: Larkum, A. W. D., Orth, R. J., and Duarte, C. M., Kluwer, 2004.

Middelburg, J. J., Soetaert, K., and Herman, P. M. J.: Empirical relationships for use in global diagenetic models, Deep-Sea Res. I, 44, 327-344, 1997a.

Middelburg, J. J., Nieuwenhuize, J., Lubberts, R. K., and van de Plassche, O.: Organic carbon isotope systematics of coastal marshes, Est. Coast. Shelf. Sci., 45, 681-687, 1997b.

Middelburg, J. J., Duarte, C. M., and Gattuso, J.-P.: Respiration in coastal benthic communities, in: Respiration in aquatic ecosystems, edited by: del Giorgio, P. A. and Williams, P. J. le B., Oxford Univ. Press, 2005.

Milliman, J. D. and Syvitski, J. P.: Geomorphic/tectonic control of sediment discharge to the ocean: the importance of small mountainous rivers, J. Geol., 100, 525-544, 1992.

Patrick, W. H. and Delaune, R. D.: Subsidence, accretion, and sea-level rise in South San Francisco Bay Marshes, Limnol. Oceanogr., 35, 1389-1395, 1990.

Robinson, C. and Williams, P. J. le B.: Respiration and its measurement in surface marine waters, in: Respiration in aquatic ecosystems, edited by: del Giorgio, P. A. and Williams, P. J. le B., Oxford Univ. Press, 2005.

Romero, J., Pérez, M., Mateo, M. A., and Sala, E.: The belowground organs of the Mediterranean seagrass Posidonia oceanica as a biogeochemical sink, Aquat. Bot., 47, 13-19, 1994.

Smith, S. V.: Marine macrophytes as a global carbon sink, Science, 211, 838-840, 1981.

Tomlinson, P. B.: The botany of mangroves, Cambridge Univ. Press., 1994,

Valiela, I., Bowen, J. L., and York, J. K.: Mangrove forests: one of the world's threatened major tropical environments, Bioscience, 51, 807-815, 2001.

Vörösmarty, C. J., Meybeck, M., Fekete, B., Sharma, K., Green, P., and Syvitkski, J.: Anthropogenic sediment retention: Major global-scale impact from the population of registered impoundments, Global Planet. Change, 39, 169-190, 2003.

Walker, D. I. and Woelkerling, W. J.: Quantitative study of sediment contribution by epiphytic coralline red algae ins eagrass meadows in Shark bay, Western Australia, Marine Ecology Progress Series, 43, 71-77, 1988.

Widdows, J., Blauw, A., Heip, C. H. R., Herman, P. M. J., Lucas, C. H., Middelburg, J. J., Schmidt, S., Brinsley, M. D., Twisk, F., and Verbeek, H.: Role of physical and biological processes in sediment dynamics (sedimentation, erosion and mixing) of a tidal flat in Westerschelde estuary, S. W. Netherlands, Mar. Ecol. Prog. Ser., 274, 41-56, 2004.

Woodroffe, C.: Mangrove sediments and geomorphology, In: Tropical Mangrove Ecosystems, edited by: Robertson, A. I. and Alongi, D. M., AGU, Washington, DC, 7-41, 1992.

Woodwell, G. M., Rich, P. H., and Mall, C. S. A.: Carbon in estuaries, In: carbon in the biosphere, edited by: Woodwell, G. M. and Pecari, E. V., U.S. AEC, 22, 1. 240, 1973. 